\title{
Detection of seed mycoflora associated with Indian bean cultivars
}

Dhara R. Prajapati and P.R. Patel*

Department of Plant Pathology, N. M. College of Agriculture, Navsari Agricultural University, Navsari (Gujarat) India

\section{ARITCLE INFO}

Received : 20.01 .2020

Revised : 21.02 .2020

Accepted : 05.03.2020

\section{KEY WORDS :}

Indian bean, Cultivars, Seed mycoflora, Agar plate method, Blotter paper method

*Corresponding author:

Email : prpfrs.nau@gmail.com

\begin{abstract}
Seed mycoflora detected in agar plate method was Rhizopus stolonifer, Fusarium oxysporum, Curvularia lunata, Aspergillus niger, Aspergillus flavus, Alternaria alternata and Penicillium sp. in five different Indian bean cultivars. Overall 5.35 to 23.94 per cent seeds showed various seed mycoflora. Aspergillus niger developed maximum colonies and Penicillium sp. the least. Similarly seed mycoflora was detected in blotter paper method, 13.49 to 35.90 per cent seeds showed various seed mycoflora. Aspergillus niger developed maximum colonies and Rhizopus stolonifer the least. Per cent seed mycoflora was high in blotter paper mehod compared to agar plate method.
\end{abstract}

How to view point the article : Prajapati, Dhara R. and Patel, P.R. (2020). Detection of seed mycoflora associated with Indian bean cultivars. Internat. J. Plant Protec., 13(1) : 40-44, DOI : 10.15740/HAS/IJPP/13.1/40-44, Copyright@ 2020: Hind Agri-Horticultural Society. 